\title{
MENDUDUKKAN ULANG POPULISME ISLAM: KARAKTER POLITIK IDENTITAS DAN PERKEMBANGANNYA DI INDONESIA
}

\author{
Muhammad Naufan Rizqullah, Mulawarman Hannase
}

Universitas Indonesia (UI) Depok, Jawa Barat Indonesia

Email:m.naufan@ui.ac.id, mulawarmanhannase@ui.ac.id

\begin{tabular}{l}
\hline INFO ARTIKEL \\
\hline Diterima \\
17 Juni 2021 \\
Direvisi \\
18 Juni 2021 \\
Disetujui \\
21 Juni 2021 \\
\hline
\end{tabular}

Keywords:

populism, democracy, democratic depolitization, neoliberal globalization, fragmentation of Islamic populism

\section{ABSTRACT}

Populism is one of the most important analytical units in reading socio-political constellations in democratic countries, including Indonesia these days. Post-Reform democratization goes hand in hand with the strengthening of identity politics in the fight for power, as it culminates in the phenomenon of the large mobilization of conservative Muslim forces and racist political rhetoric in the 2017 JAKARTA Gubernatorial Election. This article tries to analyze in general, by trying to explain right populism as a major marker of world political discourse is a symptom of a democracy that experienced post-Cold War depolitization with a crisis of representation as a result. Furthermore, it is a response to the social dislocation resulting from globalized neoliberalism practices. In this article try to analyze the phenomenon of Islamic Populism by using qualitative research methods by using the approach of democracy as an analysis tool considering Islamic populism in Indonesia has always been related to the problem of democratization and reprentasi of Muslims in the political scene. Thus, this paper seeks to find a cause as well as a precondition that allows the development of right populism in the contemporary era with a specific case on the characteristics of Islamic populism in Indonesia and trying to explain how the implications of Islamic populism for the future of democracy in Indonesia. From the various explanations above that Populism is enough to make a threat in a democracy because it uses more sentiments and arguments in its political process. While the phenomenon in Indonesia the occurrence of various inequalities and representation crises resulting in the strengthening of Islamic populism that results in fragmentation in society and Muslims themselves.

$\begin{array}{ll}\text { How to cite: } & \text { Rizqullah, Muhammad Naufan, Mulawarman Hannase (2021) Mendudukkan Ulang Populisme } \\ & \text { Islam: Karakter Politik Identitas Ddn Perkembangannya Di Indonesia. Jurnal Syntax Admiration } \\ & \text { 2(6). https://doi.org/10.46799/jsa.v2i6.256 } \\ \text { E-ISSN: } & \text { 2722-5356 } \\ \text { Published by: } & \text { Ridwan Institute }\end{array}$




\begin{tabular}{|c|c|c|}
\hline & & ABSTRAK \\
\hline $\begin{array}{l}\text { Kata Kunci : } \\
\text { populisme, } \\
\text { depolitisasi } \\
\text { globalisasi } \\
\text { fragmentasi } \\
\text { Islam }\end{array}$ & $\begin{array}{l}\text { demokrasi, } \\
\text { demokrasi, } \\
\text { neoliberal, } \\
\text { populisme }\end{array}$ & $\begin{array}{l}\text { Populisme merupakan salah satu unit analisis yang cukup } \\
\text { penting dalam membaca konstelasi sosial-politik di } \\
\text { negara-negara demokratis, termasuk Indonesia hari-hari } \\
\text { ini. Demokratisasi pasca-Reformasi berjalan beriringan } \\
\text { dengan menguatnya politik identitas dalam pertarungan } \\
\text { perebutan kekuasaan, seperti yang memuncak pada } \\
\text { fenomena besarnya mobilisasi kekuatan Muslim } \\
\text { konservatif dan retorika politik yang rasialis dalam } \\
\text { Pemilihan Gubernur DKI Jakarta 2017. Artikel ini } \\
\text { mencoba menganalisis secara umum, dengan mencoba } \\
\text { menjelaskan populisme kanan sebagai penanda utama } \\
\text { wacana politik dunia merupakan simtom dari demokrasi } \\
\text { yang mengalami depolitisasi pasca-Perang Dingin } \\
\text { dengan krisis representasi sebagai akibatnya. Lebih jauh, } \\
\text { hal tersebut merupakan tanggapan terhadap dislokasi } \\
\text { sosial yang diakibatkan oleh praktik-praktik } \\
\text { neoliberalisme yang mengglobal. Dalam artikel ini } \\
\text { mencoba menganalisis fenomena Populisme Islam } \\
\text { dengan menggunakan metode penelitian kualitatif dengan } \\
\text { memakai pendekatan demokrasi sebagai alat analisis } \\
\text { mengingat populisme Islam di Indonesia selalu berkaitan } \\
\text { dengan permasalahan demokratisasi dan reprentasi kaum } \\
\text { Muslim dalam kancah politik. Dengan demikian, tulisan } \\
\text { ini berupaya mencari sebab sekaligus prakondisi yang } \\
\text { memungkinkan berkembangnya populisme kanan dalam } \\
\text { era kontemporer dengan spesifikasi kasus pada } \\
\text { karakteristik populisme Islam Di Indonesia dan berusaha } \\
\text { menjelaskan bagaimana implikasi populisme Islam bagi } \\
\text { masa depan demokrasi di Indonesia. Dari berbagai } \\
\text { penjelasan diatas bahwa Populisme cukup menjadikan } \\
\text { ancaman dalam demokrasi karena lebih banyak } \\
\text { menggunakan sentimen dan argumen dalam proses } \\
\text { politiknya. Sedangkan fenomena di Indonesia terjadinya } \\
\text { berbagai ketimpangan dan krisis representasi sehingga } \\
\text { menguatnya populisme Islam yang mengakibatkan } \\
\text { fragmentasi di masyarakat dan Umat Islam itu sendiri. }\end{array}$ \\
\hline
\end{tabular}

\section{Pendahuluan}

Populisme menjadi sebuah kerangka teori yang dapat digunakan sebagai dasar analisis untuk melihat sekaligus menelisik serangkaian aksi massa dalam geliat mobokrasi saat Pemilihan Kepala Daerah (Pilkada) DKI Jakarta 2017 silam yang menggunakan dalil-dalil kitab suci sebagai legitimasinya: "Aksi Bela Islam" atau "Aksi 212". Sehingga, aksi protes massal jalanan tersebut secara sugestif mampu membawa kepentingan politik praktis dari kompetisi elektoral yang duniawi ke urusan surga dan neraka yang berdimensi ukhrawi.(Avit Hidayat, 2017) Kondisi tersebut kemudian 
secara dogmatis sangat menguras psikis publik, baik di kelompok yang menyetujui maupun menentang unjuk rasa tersebut. Terjadi polarisasi amat tajam yang bersemayam dalam tubuh masyarakat melalui pencapaian serta eksklusi sosial, bahkan hingga kini. Segregasi ruang sosial itu bisa dengan mudah kembali memanas bila ada peristiwa politik yang memantiknya dan menjadi bom waktu yang siap meledak bila menemukan momen politik yang tepat, yakni saat penyelenggaraan pemilihan umum. Sungguhpun dalam Pemilihan Presiden dan Wakil Presiden 2019, Ma'ruf Amin, Ketua Majelis Ulama Indonesia (MUI) yang sangat berperan dalam "Aksi Bela Islam”, pada akhirnya mendampingi Joko Widodo, petahana sekaligus figur yang secara emosional dekat pada kelompok yang menentang aksi, gelombang populisme Islam tidak mereda, malah tak terbendung dan keterbelahan sosial itu kian tampak (BBC.com, 2019)

Secara umum, peberbagai analisis bernuansa populer maupun ilmiah menyebut bahwa populisme semacam itu, sebagaimana juga menjadi fenomena di berbagai tempat, dibaca melalui pendekatan yang berorientasi pada ide dan retorika para pemimpin populis dalam kemampuannya memobilisasi massa agar terorganisasi dengan solid (Hardiman, 2020) atau pendekatan yang melihat populisme sekadar sebagai suatu gaya berpolitik (political style) (Cosovschi, 2018).

Lebih spesifik, dalam konteks Indonesia, pendekatan kultural dan analisis yang lebih menekankan aspek politik keamanan dalam memahami dan merespon menguatnya populisme Islam sebagai varian dari populisme kanan, yang celakanya justru memberi landasan bagi kaum populis Islam untuk memproduksi ulang narasi yang eksklusioner dan illiberal di satu sisi, sekaligus mempersilakan negara masuk dalam rezim eksklusioner dan illiberal pula di sisi lain. Maksudnya, kebijakan negara yang berbasis ketakutan berlebih terhadap menguatnya populisme Islam dituangkan melalui Perppu No. 2 Tahun 2017 yang menjadi instrumen pembubaran paksa organisasi massa penyokong "Aksi 212": Hizbut Tahrir Indonesia (HTI) dan baru belakangan Front Pembela Islam (FPI) (Rahmat Nurhakim, Fitria Chasna Farisa, 2020). Rizieq Shihab sebagai aktor utama yang memelopori kebangkitan populisme kanan di Indonesia pun pada akhirnya dipidana. Padahal faktanya, sebagaimana akan dijelaskan kemudian, alihalih kian menguat, fragmentasi justru menjadi ciri populisme Islam yang menonjol di Indonesia sebagai akibat dari represi panjang negara kapitalis otoriter Orde Baru. Kendati mobilisasi populisme Islam konservatif berhasil mengantarkan Anies Baswedan dan Sandiaga Uno menjadi pemenang Pilkada Jakarta 2017 dan mampu mendominasi ruang politik Pilpres 2019, trajektori politik Islam diprediksi memiliki kemungkinan yang sulit untuk dapat bertumbuh. Sekalipun berprospek, mereka bermakna hanya ketika kompetisi elektoral berlangsung, namun tidak menjadi subjek politik penting dalam formulasi dan pengambilan kebijakan publik.

Terdapat beberapa penelitian sebelumnya yang membahas dan menganalisa peristiwa peristiwa Populisme Islam di Indonesia. Setidaknya terdapat 5 penelitian yang membahas atau menganalisa permasalahan-permasalahan yang mempunyai keterkaitan dengan peristiwa Populisme Islam di Indonesia. Andi Eka Putra misalnya, dalam penelitian berjudul "Populisme Islam: Tantangan atau Ancaman bagi Indonesia?" melakukan penelitian mengenai peran politik populisme Islam di Indonesia sebagai hal 
yang wajar dan berlebihan jika dianggap ancaman. Sementara itu penelitian dari Rangga Kusumo dan Hurriyah dengan penelitian berjudul "Populisme Islam di Indonesia: Studi Kasus Aksi Bela Islam oleh GNPF-MUI Tahun 2016-2017" menganalisa Populisme Islam dan aksi 212 sebagai wujud aksi dari Populisme Islam. Begitu pula dengan penelitian yang dilakukan oleh Syamsul Arifin dengan judul "Islam, Populisme dan Masa Depan Demokrasi di Indonesia yang memiliki fokus penelitian mengenai demokrasi dan Islam memiliki keterhubungan yang mengarah kepada terjadinya populisme Islam. Sementara itu penelitian dari Irfan Prayogi dan Fernanda Putra Adela mencoba menganalisis Populisme Islam dengan konteks Pilkada DKI 2017 sebagai penanda kebangkitan politik kaum Islam dengan judul tulisan "Populisme Islam dan Imajinasi Politik dalam Pilkada DKI Jakarta 2017". Sementara itu Iradhad Taqwa Sihidi, Ali Roziqin, dan Dedik Fitra Suhermanto, mencoba menganalisa Populisme Islam yang muncul dalam Pemilihan Presiden 2019 dengan Tulisan berjudul "Pertarungan Populisme Islam dalam Pemilihan Presiden 2019".

Melihat dari penjabaran di atas maka bisa dikatakan belum ada yang melakukan penelitian Populisme Islam dengan fokus penelitianberupaya menafsirkan ulang fenomena yang terjadi dengan menelaah fenomena politik identitas dan karakter populisme Islam di Indonesia dan perkembangannya. Pada intinya penelitian ini akan menguraikan bahwa pengarusutamaan pendekatan sosiologis dan demokrasi untuk membaca karakter dan perkembangan Populisme Islam di Indonesia.

\section{Metode Penelitian}

Penelitian ini menggunakan penelitian kualitatif dengan menggunakan analisis eksplorasi. Mengingat penelitian ini akan membahas tentang populisme Islam dan perkembangannya di Indonesia, maka pendekatan penelitian kualitatif adalah pendekatan yang dibutuhkan untuk mengungkapkan masalah penelitian. Penulis dalam hal ini menggunakan penelitian pustaka (library research), di mana peneliti mengamati objek penelitian melalui berbagai bahan pustaka berupa buku, jurnal, laporan penelitian sebelumnya, dan media internet (Creswell \& Zhang, 2009). Sedangkan untuk penggunaan data akan mengambil dari beberapa sumber seperti: berita-berita terkait isu di atas serta beberapa penelitian terdahulu.

\section{Hasil dan Pembahasan}

1. Populisme Dan Ancaman Demokrasi

Sebelum memahami Islam politik di Indonesia dan belahan dunia lain sebagai bentuk "populisme baru" yang lahir dari pelbagai kontradiksi, yang tercipta bersamaan dengan perkembangan kapitalisme dan globalisasi ekonomi, terlebih dahulu pada bagian ini akan berupaya mengulas populisme, sebagaimana telah disinggung sebelumnya, dalam pengertian lebih luas dan lintas pendekatan, serta menunjukkan letak permasalahannya dalam lapangan demokrasi. Populisme bukanlah tradisi baru dalam politik modern. Aksi massa yang kecewa terhadap demokrasi karena praktik institusionalisme dan prosedural di dalamnya justru melahirkan banyak bias yang berujung pada munculnya para oligark baru serta tersumbatnya aspirasi dan tuntutan publik karena mandeknya kaderisasi dan 
komunikasi politik pada akhirnya berupaya mencari celah alternatif untuk membangun representasi kekuasaan di luar elite predatoris. Para pemimpin populis atau tokoh politik dengan kepentingan tertentu menangkap kekecewaan publik terhadap jalannya demokrasi yang demikian, mereka menawarkan jalan alternatif dengan mengonsolidasikan diri atas nama rakyat (the pure people) untuk melawan hegemoni elite yang korup dan menindas (the corrupt elite). Rakyat sebagai demos diromantisasi kembali karena ia sebagai pemegang kekuasaan tertinggi di atas lembaga trias politika; sebuah bangunan mapan dari demokrasi. Romantisasi "rakyat" menjadi kata kunci penting yang menarik untuk mengembalikan nilai-nilai substantif demokrasi ke dalam praktik pemerintahan. Kendati populus atau rakyat terlibat di dalam gerakan alternatif tersebut, namun sesungguhnya rakyat dalam populisme dipahami berbeda dari rakyat dalam definisi demokrasi. Demos dimaksudkan pada "para warga negara, pekerja, asosiasi-asosiasi, partai-partai, dan seterusnya", sementara rakyat dalam populisme diartikan sebagai "massa yang tidak terdiferensiasi”. Artinya, aksi massa yang bersuara atas nama demokrasi itu sebenarnya tidak pernah demokratis karena secara tidak langsung mereduksi marwah demokrasi dengan menyampingkan pelbagai macam tahapan dan prosedur yang semestinya ditempuh. Fasilitas demokrasi, seperti hak berdemonstrasi dipakai untuk tujuan populis yang tidak pernah demokratis: menelikung saluran konstitusional demi kepentingan politik praktis tertentu. Di sisi lain, ketidakpercayaan publik terhadap lembaga-lembaga publik, semisal partai-partai dan politik perwakilan, menunjukkan adanya problem dalam relasi negara dan masyarakat. Hal tersebut menjadi preseden buruk bagi indikator capaian demokrasi suatu negara. Pada intinya, gerakan populis menjadi penting untuk dipahami karena ia memiliki dua daya terhadap eksistensi demokrasi, yakni sebagai aksi kuratif atau represif. Dan di titik itulah letak permasalahannya, populisme memiliki hubungan yang sulit dengan demokrasi karena di antara populisme dan demokrasi, dalam bahasa F. Budi Hardiman, terdapat intimitas sekaligus pengkhianatan. Pada umumnya populisme lahir dari rahim ketimpangan sosial, teralienasi secara politik, dan ketidakpercayaan pada elite politik. Karenanya, sebagai aksi kuratif, gerakan populis kanan sesungguhnya berupaya menelanjangi problem sosial yang selama ini ditutupi: bahwa demokrasi telah dibajak oligarki. Yang menjadi soal adalah ketika fakta tersebut dijadikan alasan oleh kaum populis untuk bertindak eksesif, yaitu menafikan prosedur-prosedur mapan, seperti mekanisme undang-undang dan peradilan karena menanggap semua itu semata sebagai alat kepentingan para oligark. Di samping itu, gerakan populis kanan, yang membedakannya dengan populisme konvensional, kian represif karena politisasi sentimen dan narasi eksklusionernya: anti-imigran Muslim di Eropa Barat dan Amerika Serikat era Trump atau anti-aseng di Indonesia. Mereka menolak universalisme nilai-nilai dengan membela partikularisme yang bertujuan memproteksi, misalnya, kepentingan nasional yang sempit di Eropa dan AS (ultra-nasionalistis) atau primordialisme agama dalam artian Islam konservatif di Indonesia (hiper-religius). 
Tak pelak Lars Rensmann menyebut musuh besar populisme kanan adalah elitisme dan pluralisme. Dengan kata lain, populisme kanan berusaha menjadi payung besar diversifikasi kepentingan justru melalui simbol kuat berupa identitas yang mampu memobilisasi massa dalam jumlah besar. Hal tersebut berbeda dengan gerakan masyarakat warga (civil society) pada umumnya yang lebih mengedepankan kolektivitas gerakan dengan isu kesetaraan antar warga negara dan keadilan sosial yang lebih inklusif.

Selain aspek penguatan identitas dan isu sebagai simbol perekat, populisme bersangkutan pula pada figuritas. Sebagaimana diketahui, para pemimpin populis kerap menyulut emosi massa dengan ujaran-ujaran kebencian pada, misalnya, para imigran, kelompok minoritas, dan bahkan juga kepada pemerintahan demokratis yang sah, yang dianggap telah dikooptasi para elite predatoris. Para pemimpin populis seperti Trump di Amerika, Le Pen di Prancis, Geert Wilders di Belanda, Lutz Bachmann di Jerman, juga Narendra Modi di India serta Rizieq Shihab di Indonesia, berfungsi sebagai ego-ideal para pengikutnya masing-masing: mereka dipuja dan diidealkan sedemikian rupa sehingga segala tindakannya patut diikuti dan cenderung selalu dianggap benar. Daya kritis massa pengikut hilang seiring proses personalisasi politik tersebut. Instrumentalisasi identitas pribumi atau agama untuk tujuan-tujuan bersama mampu mengaburkan jarak antara massa dan figur pemimpinnya. Padahal sebenarnya massa pengikut, juga para penggerak kedua, ketiga, dan seterusnya, tidak pernah mengetahui tujuan politis lain dari para pemimpin mereka. Hanya para pemimpin utama dan tentu saja para oligark yang dapat mengambil keuntungan politis dari aksi protes bersama itu, sebab dimungkinkan bahwa mereka juga merupakan bagian dari oportunisme politis yang justru sedang mereka lawan. Alhasil, massa tidak lebih dari sekadar perkakas para elite predatoris yang ingin menjaga aset dan pengaruh mereka dalam kocok ulang perebutan kekuasaan dan kontrol atas sumber daya.

Pada akhrinya, sekalipun populisme tengah menjadi penanda utama wacana politik dunia karena cita-citanya mengoreksi kemapanan, tetapi Karin Priester menyimpulkan bahwa, dalam praktiknya, populisme kerap dimaknai negatif setidaknya karena dua alasan, yakni melakukan emosionalisasi dan personalisasi politik. Pertama, gerakan populis lebih sering menawarkan slogan-slogan antagonistik dan sentimen-sentimen primordial untuk membakar emosi publik pada saat demokrasi sebagai ruang politik selalu mengupayakan dirinya diisi oleh sebuah proses rasional, dalam artian melibatkan kepentingan yang dapat dinalar publik. Sentimental politik dan politisasi sentimen semacam itu merupakan gaya berpolitik (political style) populisme yang sudah menjadi pakem. Kedua, dalam populisme politik diserahkan pada figur pemimpin. Akibatnya, politik tidak lebih dari sekadar gerakan aksi yang berpusat pada kepentingan figur tersebut. Padahal politik bukan perkara personal, melainkan bersangkutan dengan kepentingan publik. Politisasi sentimen yang berujung pada privatisasi politik membuat gerakan populis itu cenderung berbahaya bagi pertumbuhan demokrasi yang menghendaki argumen 
dan rasionalitas publik. Di sini, gerakan demokratis masyarakat warga (civil society) sebagai antonim terutama dari gerakan populis kanan menjadi demikian penting karena dua hal. Pertama, berbeda dengan gerakan populis kanan yang diorganisasi dari luar oleh para pemimpinnya, gerakan masyarakat warga berangkat dari inisiatif organik para individu sebagai warga negara. Kedua, alih-alih menelikung saluran konstitusional seperti dilakukan gerakan populis kanan, gerakan masyarakat warga berusaha memastikan politik tetap dibawa dan berada dalam kerangka sistem hukum.(Hardiman, n.d.) Walaupun dalam berbagai kesempatan populisme kanan yang diwakili kelompok Islamis dalam negara demokrasi seringkali terlibat dalam kontestasi, untuk melakukan yang disebut dengan "Normalisasi Politik" untuk menerapkan nilai Syariah dan doktrin yang diyakini. (Hannase, 2020) Populisme pada dasarnya lebih mengutamakan sentimen dibandingkan argumen; pondasi bila ingin dikatakan demokrasi memiliki tubuh yang sehat.

Dengan demikian, populisme memperlemah daya sintas demokrasi. Populisme juga bukanlah solusi atas problem sosial seperti yang telah dijelaskan sebelumnya, melainkan simtom sosial akibat demokrasi yang mengalami depolitisasi. Kendati begitu, pertanyaannya, mengapa populisme tetap dipilih sebagai alternatif gerakan dewasa ini ? Bagian berikutnya akan membahas pertanyaan itu, terutama berupaya memahami kondisi yang memungkinkan berkembangnya populisme kanan dalam era kontemporer dengan spesifikasi kasus pada karakteristik populisme Islam di Indonesia.

2. Krisis Representasi, Oligarkisasi Masyarakat, dan Fragmentasi Populisme Islam

Populisme adalah proksi dalam demokrasi. Artinya, populisme sesungguhnya dapat digunakan untuk mengukur derajat demos sebagai pemegang supremasi kedaulatan publik. Meskipun populisme didefinisikan negatif sebagai mobokrasi yang digerakkan melalui pelbagai simbol, baik berupa isu, identitas, figur, maupun masalah tertentu yang dinilai penting dan harus segera dicari penyelesaiannya, pada saat itu juga populisme dalam artian massa yang tumpah ruah di jalanan sebenarnya memberikan kritiknya pada demokrasi yang menjadi kian prosedural dan "konstitusional", meninggalkan dimensi politiknya tentang adanya kontestasi isu dan kepentingan yang ketat. Demokrasi pada akhirnya memosisikan dirinya berjarak dengan demos yang membentuknya. Setidaknya karena melalui mekanisme elektoralnya, demokrasi nyaris tidak menyediakan pilihan-pilihan politik alternatif sehingga berbagai aspirasi dan tuntutan tidak sepenuhnya terwakilkan dalam lembaga-lembaga representatif seperti partai politik. Dengan kata lain, populisme muncul juga karena demokrasi mengalami krisis representasi. Populisme disambut baik dan mendapat banyak dukungan karena dipandang mampu mengembalikan demos yang terpinggirkan dan tak digubris, karena sistem representasi dalam demokrasi yang tersedia telah dikuasai konsensus antar-elite dan kompromi partai. Perkembangan demokrasi di dunia dewasa ini, meski dengan bentuk dan derajat berbeda, tengah menghadapi persoalan nyaris sama, yakni kian 
hilangnya dimensi politik dari dalam dirinya, terutama terkait dengan globalisasi neoliberal yang melalui berbagai intervensinya dalam masyarakat menunjang bekerjanya "logika pasar" yang cenderung membuat politik sekadar sebagai urusan teknokratis administratif dan penegakan hukum. Semisal, di negara-negara Eropa Barat dan Skandinavia, gerakan progresif sebagai alternatif politik dalam demokrasi tampak melemah. Tidak terkonsolidasinya agenda politik progresif tersebut pascaPerang Dingin lebih disebabkan oleh bangkrutnya negara kesejahteraan (welfare state) akibat membengkaknya demografi kelas menengah non-produktif di satu sisi, serta semakin menguatnya individualisasi yang ditandai kian berkurangnya peran negara dalam memberikan jaminan sosial kepada masyarakat di sisi lain. Hal tersebut membuat partai-partai progresif dalam usahanya mengamankan posisinya dalam kompetisi electoral pada akhirnya harus mendukung proyek-proyek modernisasi neoliberal untuk lebih memperhatikan kepentingan kelas menengah non-produktif ketimbang, antara lain, tuntutan kelas pekerja yang notabenenya sebagai basis sosial partai (Mudhoffir et al., 2017). Kondisi dalam bahasa Chantal Mouffe, pasca-politik itu membuat partai-partai progresif di Eropa kian meninggalkan agenda reorganisasi tatanan kapitalisme neoliberal untuk tujuantujuan kesetaraan, yaitu kondisi sosial yang lebih baik dan redistribusi ekonomi yang lebih adil. Intinya, jalan ketiga (the third way) (Giddens \& Mahardika, 1919) yang ditempuh tersebut, secara umum, tidak menjadikan neoliberalisme sebagai antagonisme politik partai, melainkan justru secara sadar ikut melanggengkan agenda-agenda politiknya (Mouffe, 2005). Akibatnya, kelas pekerja dan kelompokkelompok sosial yang terpinggirkan berupaya mencari saluran alternatif lain yang mampu mengartikulasikan pelbagai tuntutan dan kepentingan mereka. Di samping itu, kehadiran para imigran Muslim yang mencari suaka akibat peperangan di Timur Tengah turut mempercepat eskalasi kekecewaan terhadap lembaga kekuasaan yang menjamin penghidupan para imigran tersebut, apalagi mereka tidak diberi beban pajak. Akibat lanjutannya: layanan sosial bagi kelas pekerja pun dikurangi. Tepat pada keadaan seperti itulah populisme kanan sebagai alternatif gerakan berkembang dan cepat menguat, memperkenalkan diri sebagai representasi dari gelombang kekecewaan yang dibalut politik identitas yang eksklusioner, yakni anti-imigran, bahkan anti-Muslim (Mudhoffir et al., 2017). Di Indonesia, krisis politik berbasis representasi dewasa ini setidaknya berakar dari sejarah yang panjang. Depolitisasi demokrasi terutama dalam wujud kebijakan massa mengambang (floating mass) rezim pembangunan Orde Baru sekaligus upayanya menutup pelbagai kemungkinan munculnya antagonisme politik, baik gerakan progresif maupun kelompok Islam, atas nama keamanan dan ketertiban umum nyatanya bukan hanya menghasilkan masyarakat yang apolitis serta gerakan masyarakat warga (civil society) yang terfragmentasi, melainkan pula Lembagalembaga representatif, misalnya, partai politik kehilangan kemampuannya dalam memobilisasi dan mengorganisasikan basis politiknya.(Bourchier \& Hadiz, 2003) Terlihat dari terkooptasinya pelbagai organisasi sosial, termasuk organisasi 
bercorak keagamaan seperti Islam, organisasi buruh, petani, serta asosiasi-asosiasi lainnya melalui kebijakan modernisasi atas nama pembangunan ala negara kapitalis otoriter Orde Baru.(Moertopo, 1973) Pasca-Orde Baru dalam era neoliberalisme ini tampak tidak banyak perbedaan. Karakter dimensi politik dalam proyek demokratisasi tetap bertolak pada tradisi depolitisasi dan teknokrasi yang diwariskan rezim pembangunan Orde Baru. Proyek demokratisasi untuk mengubah rezim otoritarianisme Orde Baru tidak sempat memfasilitasi terbentuknya agensiagensi demokratis dalam bentuk gerakan masyarakat warga yang terorganisasi. Maksudnya, terfragmentasinya gerakan pro demokrasi dan terlalu fokusnya oposan dalam usaha meruntuhkan rezim membuat mereka gagal atau tidak cukup waktu mendiskusikan agenda politik bersama pasca Orde Baru. Akibatnya, tatanan kekuasaan sebelumnya yang memang bersifat oligarkis terbawa dan ikut masuk dalam arena politik baru yang demokratis. (V. Hadiz \& Robison, 2004) Kondisi demikian memunculkan kesadaran dan menormalisasi anggapan bahwa politik itu hanya milik elite dan urusan elite, sementara rakyat dikonstruksi terus-menerus sebagai objek yang diurusi elite semata melalui intervensi pembangunan rezimrezim teknokrasi. Pada akhirnya, elite lama yang menikmati kekuasaan di era Orde Baru ikut kembali menguasai lembaga-lembaga demokrasi, bahkan menentukan arah dari proses demokratisasi. Sementara itu, kelompok borjuasi Tionghoa yang mendominasi kapital kian bertambah kekayaannya dan membuat mereka memiliki pengaruh yang jauh lebih besar dalam konstelasi kekuasaan dibanding era sebelumnya. Hal tersebut dapat dengan mudah diamini ketika partai-partai politik yang karena tidak memiliki kelas kapitalis yang kuat juga karena ketiadaan basis sosial yang mengakar dan kuat mereka bergantung pada kaum borjuasi Tionghoa untuk membentuk aliansi predatoris dalam kontestasi elektoral. Alhasil, mekanisme politik demokratis dilangsungkan hanya sebagai ajang dalam arena baru perebutan kekuasaan dan akumulasi aset para elite predatoris. Keadaan tersebut menandai terjadinya krisis representasi di Indonesia yang terus-menerus direproduksi sampai sekarang.

Selain semakin menghilangnya dimensi politik dalam demokrasi yang berujung pada terjadinya krisis representasi, situasi pasca-politik juga merupakan akibat dari, Chantal Mouffe menyebutnya, “oligarkisasi” masyarakat.(Mouffe, 2005) Maksudnya, fenomena itu tak bisa dilepaskan dari agenda-agenda pembangunan neoliberal yang lebih sering melahirkan ketimpangan sosial, pekerja prekariat, dan kondisi kelas menengah yang rentan pada satu sisi dan memfasilitasi aliansi politik-bisnis atas kontrol terhadap sumber daya publik pada sisi lainnya. Bukti paling nyata dapat dilihat dari bertambah banyaknya jumlah pekerja prekariat yang mengalami ketidakpastian, ketidakamanan, dan ketidakstabilan kerja; produk dari kebijakan ketenagakerjaan yang fleksibel, yang menjadi salah satu penanda modernitas ala neoliberalisme. (Natalia, 2021) Pelbagai situasi kerja yang kian memburuk membuat pekerja prekariat rentan mengalami psikis yang selalu gelisah, marah, keadaan tak tentu arah, dan merasa teralienasi. Fakta tidak terkonsolidasinya gerakan progresif 
yang fasih mengartikulasikan isu-isu kesetaraan sosial-ekonomi membuat gelombang psikis yang kecewa itu menjadi beralih dan memungkinkannya untuk dimobilisasi para pemimpin populis kanan. Sementara di Eropa Barat, akumulasi kekecewaan itu dibalut melalui narasi dan slogan-slogan ultra-nasionalistis, di Indonesia kondisi itu dibungkus dengan narasi dogmatis agama serta slogan anti-aseng (baca: anti-Cina atau anti-Tionghoa) sebagaimana telah dijelaskan pada bagian sebelumnya.

Selain karena semakin mapannya kelompok borjuasi Tionghoa pasca-Orde Baru, kesenjangan ekonomi tersebut terlihat, misalnya, dalam laporan Credit Suisse pada 2016 yang menunjukkan bahwa 1 persen orang terkaya di Indonesia (sekitar 2,6 juta orang) menguasai sekitar 49 persen atau hampir setengahnya dari total kekayaan Indonesia, sementara 10 persen orang terkaya (26 juta orang) memiliki 77 persen total kemakmuran Indonesia. Sebaliknya, hanya 1,4 persen dari total kekayaan aset negara dimiliki 100 juta orang termiskin (40 persen) Indonesia. Problem struktural warisan rezim pembangunan Orde Baru itu berkelindan dengan proporsi pekerja prekariat yang pada umumnya bekerja di sektor informal yang cukup besar mencapai 53,6 persen. (Kercheval et al., 2013) Angka tersebut disebabkan, antara lain, oleh gagalnya sektor formal dalam menciptakan lapangan pekerjaan yang lebih pasti, aman, dan stabil. Akan tetapi, pekerja di sektor formal pun mengalami ketidakpastian, ketidakamanan, dan ketidakstabilan akibat maraknya aturan outsourcing maupun kontrak jangka pendek produk kebijakan ketenagakerjaan yang fleksibel khas neoliberalisme.(Tjandraningsih, 2013) Selain itu, Asia Development Bank 2014 memperlihatkan bahwa terdapat sekitar 55 persen rumah tangga Indonesia yang terkategorikan kelas menengah terjerembap pada belenggu kemiskinan. Artinya, kelas menengah rentan (precariat middle class) yang mendominasi kelas menengah di Indonesia itu bisa kapan saja kembali jatuh miskin. Kecemasan akan terjadinya pemiskinan sosial di kalangan kelas menengah rentan tersebut, serta kekecewaan kelas pekerja prekariat atas sistem ketenagakerjaan patut diperhatikan sehubungan dengan problem berbasis identitas: kecemburuan ekonomi terhadap etnis Tionghoa. Di titik itulah populisme kanan (baca: Islam radikal) (Mansur et al., 2019) juga memungkinkan dirinya untuk muncul dan segera menguat.

Kelompok masyarakat urban dengan ekonomi rentan semacam itu, terutama kelas pekerja prekariat pada akhirnya harus menjalin relasi, salah satunya, dengan kelompok-kelompok sosial keagamaan yang menyediakan pelbagai sumber daya yang bisa dimanfaatkan untuk memperoleh akses atas pekerjaan ataupun pelbagai macam bantuan sosial yang dibutuhkan, bahkan sebagai tempat bernaung dan berlindung. Sebagai timbal-baliknya, mereka dimobilisasi untuk agenda-agenda perebutan kekuasaan dalam kontestasi elektoral. Bahkan, diminta untuk bekerja dalam bisnis keamanan yang digeluti kelompok-kelompok keagamaan yang menghendaki kekerasan.(Yasih, 2017) Di sisi lain, partai-partai atau para elite, karena sebelumnya mengalami krisis representasi akibat produk depolitisasi yang panjang sejak Orde Baru, alih-alih berupaya membangun basis sosial yang kuat 
untuk kepentingan elektoralnya, yang memang membutuhkan waktu, mereka justru mengambil jalan pintas beraliansi dengan kelompok-kelompok sipil kekerasan yang menggunakan simbol keagamaan, terutama Islam, untuk mengikuti dan memenangkan kompetisi dalam pemilu. Di sini, populisme Islam kian menemukan relevansinya dalam arena sosial yang kompleks. Sungguhpun tengah menguat karena pelbagai latar kondisi yang memungkinkannya demikian, populisme Islam di Indonesia, sebagaimana telah disinggung di atas, sesungguhnya sudah terfragmentasi sejak era Orde Baru dengan bermacam kelompok kepentingan di dalamnya. Fragmentasi tersebut dapat dilacak dari beragam jenisnya kelompok Islam yang bisa mendaku merepresentasikan "umat" sebagai proksi dari demos: dari gerakan yang mengambil jalur terorisme, juga gerakan yang menolak negara-demokrasi sampai kelompok kekerasan sipil, kelompok pengajian yang apolitis, serta partai politik Islam. Fragmentasi itu juga dapat ditemukan dari meningkatnya "religiusitas" masyarakat hari-hari ini, tetapi kecenderungan tersebut justru tidak berdampak secara signifikan pada capaian elektoral partai-partai Islam. Sekalipun Anies-Sandi yang didukung oleh aliansi atas nama "umat" mampu keluar sebagai pemenang dalam Pilkada Jakarta 2017, dan dianggap sebagai kemenangan Islam, bahkan indikator menguatnya populisme Islam, namun sebenarnya fenomena tersebut adalah buah pahit dari pertarungan kepentingan-kepentingan predatoris para oligark bisnis-politis yang berlaga (P. V. R. Hadiz, 2017).

Maksudnya, selain terfragmentasinya aliansi populisme Islam di Indonesia akibat tidak terbangunnya basis pengorganisasian yang kuat produk depolitisasi dan teknokrasi Orde Baru, juga dikarenakan tidak adanya kelas borjuasi Muslim yang kuat, keadaan semacam itu mengharuskan aliansi "umat" tersebut pada akhirnya tidak segan untuk membangun persekutuan pragmatis dengan konglomerat Tionghoa non Muslim (Ronald, 2017), yang bukan hanya ia bukan bagian dari "umat" yang mereka maksud, tetapi juga bertolak belakang dengan narasi dan retorika mereka tentang anti-aseng selama ini. Pada akhirnya, fragmentasi dan instrumentalisasi oleh elite predatoris adalah karakteristik populisme Islam di Indonesia yang menonjol, yang tidak memiliki prospek besar untuk bisa menguasai negara seperti ketakutan banyak pihak termasuk pemerintah. Karenanya, kekhawatiran berlebih terhadap menguatnya fenomena itu yang terus-menerus dinarasikan ulang oleh pemerintah bukan saja tidak perlu, tetapi bahkan bisa menjadi ancaman bagi masa depan demokrasi di Indonesia karena melanggengkan polarisasi sosial dan menghasilkan eksklusivisme dalam bentuk lain, yakni hiper-nasionalisme yang illiberal.

\section{Kesimpulan}

Dari berbagai penjelasan diatas dapat disimpulkan menjadi beberapa hal: Yang Pertama adalah adanya keterkaitan yang erat antara demokrasi dan Populisme, Beberapa fasilitas demokrasi seperti demonstrasi dan pemilu lebih banyak digunakan untuk tujuan populis yang jauh dalam nuansa yang demokratis. Dalam hubungan ini terdapat dua celah sekaligus adanya ketebutuhan saluran demokrasi untuk eksistensi populisme itu 
sendiri namun disisi lain ia mereduksi nilai-nilai demokrasi dengan nilai yang dianut oleh para kaum populis tersebut seperti mengedepankan politik identitas dalam aksiaksinya.

Kemunculan Populisme juga disebabkan karena adanya krisis representasi yang disebabkan oleh situasi politik sebelumnya di masa orde baru. Bahwa adanya berbagai kelompok massa yang terpinggirkan yang teralienasi secara politik terus berupaya mencari saluran atau alternatif politik. Sehingga mememculkan berbagai organisasi sosial baik yang memiliki latar belakang keagamaan atau suku yang terkooptasi secara sosial dan terfragmentasi secara luas sehingga para agen kekuasaan tidak dapat melakukan kontrol secara berkelanjutan terhadap organisasi organisasi tersebut. Selain itu kemunculan demokratisasi pasca orde baru juga tidak banyak hal yang berubah justru masih mewariskan tatanan kekuasaan yang oligarkis sehingga urusan politik yang masih berkutat kepada elit-elit tertentu, anggapan ini dijadikan alasan kemunculan Populisme di Indonesia khususnya dalam hal ini adalah populisme Islam. Namun Jika kita melihat Populisme Islam di Indonesia agak sulit berkembang dikarenakan: Pertama, fragmentasi-fragmentasi Umat Islam yang sudah ada sejak orde baru membuat kekuatan politiknya sangat mudah direduksi oleh agen-agen kekuasaan atau kaum Borjuasi. Sehingga seringkali kekuatan populisme Islam di Indonesia tidak bisa mencapai kemenangan secara politik. Yang kedua adalah kekuatan kapital Umat Islam juga masih sangat kurang dan tiadanya kaum borjuasi di kalangan muslim itu sendiri sehingga ketergantungan modal dengan kekuatan populisme Islam ini membuat ia tidak berkembang di Indonesia dan mengalami kebuntuan dalam perjalanannya. 


\section{BIBLIOGRAPI}

Avit Hidayat. (2017). No Title. Tempo.Com.

BBC.com. (2019). No Title. BBC,Com.

Bourchier, D., \& Hadiz, V. R. (2003). Introduction Indonesian Politics and Society: A Reader. In Indonesian Politics and Society: A Reader (pp. 1-24).Routledge.Google Scholar

Cosovschi, A. (2018). Benjamin Moffitt, The Global Rise of Populism. Performance, Political Style, and Representation, Palo Alto, Stanford University Press, 2016. Filozofija i Društvo/Philosophy and Society, 29(4), 640-642.Google Scholar

Creswell, J. W., \& Zhang, W. (2009). The application of mixed methods designs to trauma research. Journal of Traumatic Stress: Official Publication of the International Society for Traumatic Stress Studies, 22(6), 612-621.Google Scholar

Giddens, A., \& Mahardika, K. A. (1919). The Third Way: Jalan Ketiga Pembaruan Demokrasi Sosial. -.Google Scholar

Hadiz, P. V. R. (2017). The Indonesian Oligarchy's Islamic Turn. Australian Institute of International AFFairs. Google Scholar

Hadiz, V., \& Robison, R. (2004). Reorganising power in Indonesia: The politics of oligarchy in an age of markets. Routledge.Google Scholar

Hannase, M. (2020). The The Dilemma Between Religious Doctrine and Political Pragmatism: Study of Hamas in Palestine. Religió: Jurnal Studi Agama-Agama, 10(1), 54-70.Google Scholar

Hardiman, F. B. (2020). Kebangkitan Populisme Kanan dalam Negara Hukum Demokratis. Jurnal Pemikiran Sosial Ekonomi.Google Scholar

Kercheval, J., Markowitz, D., Monson, K., Read, B., \& Brown, D. (2013). Research on barriers to employment and decent work for women. International Labour Organization.Google Scholar

Mansur, A. R., Song, E.-J., Cho, Y.-S., Nam, Y.-D., Choi, Y.-S., Kim, D.-O., Seo, D.H., \& Nam, T. G. (2019). Comparative evaluation of spoilage-related bacterial diversity and metabolite profiles in chilled beef stored under air and vacuum packaging. Food Microbiology, 77, 166-172.Google Scholar

Moertopo, A. (1973). Dasar-dasar pemikiran tentang akselerasi modernisasi pembangunan 25 tahun. Yayasan Proklamasi, Centre for Strategic and International Studies. Google Scholar 
Mouffe, C. (2005). On The Political (Abingdon, Routledge).Google Scholar

Mudhoffir, A. M., Yasih, D. W. P., \& Hakim, L. (2017). Populisme Islam dan Tantangan Demokrasi di Indonesia. Prisma, 36(3), 48-59.Google Scholar

Natalia, D. L. (2021). No Title. Antara.Com.

rahmat nurhakim, Fitria Chasna Farisa, achmad nasrudin yahya. (2020). No Title. Kompas.Com.

Ronald. (2017). Alumni 212 akui bela Hary Tanoe karena banyak dibantu pemberitaan. Merdeka.Com.

Tjandraningsih, I. (2013). State-sponsored precarious work in Indonesia. American Behavioral Scientist, 57(4), 403-419.Google Scholar

Yasih, D. W. P. (2017). Jakarta's Precarious Workers: Are they a "New Dangerous Class"? Journal of Contemporary Asia, 47(1), 27-45.Google Scholar

\section{Copyright holder :}

Muhammad Naufan Rizqullah, Mulawarman Hannase (2021)

First publication right:

Jurnal Syntax Admiration

This article is licensed under:

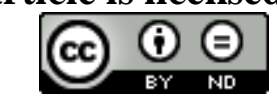

